\title{
A preliminary study on bird diversity and abundance from Wabe fragmented forests around Gubre subcity and Wolkite town, Southwestern Ethiopia
}

\begin{abstract}
Birds are among the key components of the earth's biodiversity. The main objective of this study was to assess the diversity and abundance of birds from three study sites in Wabe fragmented forests around Gubre sub city and Wolkite town, Guraghe zone, in April, 2018. Data were collected using line and point count techniques in the early morning (6:00-10:00 a.m.) and late afternoon (4:00-6:00 p.m.) for three consecutive days each in three study sites. During this study, a total of 692 birds belonging to 50 species, 29 Families and 14 Orders were recorded. From the 50 identified species of birds, $36(72 \%)$ of the species were recorded from bushland habitats, while 14 and 15 species were from riverine forest and plantation habitats respectively. Order Passeriformes was numerically the dominant order represented with 22 species which accounts $44 \%$, of the identified species, while Bucerotiformes, Charadriiformes, Ciconiformes, Coliiformes and Piciformes were the least dominant orders represented with one species each. At the family level, family Accipitridae was numerically the dominant family represented with 7 species which accounts $14 \%$, of the identified species. At species level, Helmeted guineafowl (Numida meleagris) was numerically the most dominant species. The total abundance of birds was significant difference $(\mathrm{p}=0.00)$ among the three sites. In general, highest number of individual birds were counted in bushland (410) followed by riverine forest (160) and plantation habitat (122). Furthermore, bushland area had higher value of species diversity $\left(H^{\prime}=2.89\right)$ than plantation area $\left(H^{\prime}=2.17\right)$ and riverine forests $\left(H^{\prime}=2.16\right)$. However, the study area particularly bushland and riverine forests are highly distributed due to human activities. More studies are required to make a complete list of available bird species in the study area.
\end{abstract}

Keywords: diversity, fragmented forests, relative abundance
Volume 3 Issue 5 - 2018

\author{
Seyoum Kiros,' Bezawork Afework, ${ }^{2}$ Kebeta \\ Legese' $^{\prime}$ \\ 'Department of Biology, Wolkite University, Ethiopia \\ ${ }^{2}$ Departments of Zoological Sciences, Addis Ababa University, \\ Ethiopia
}

Correspondence: Seyoum Kiros, Department of Biology, Wolkite University, Wolkite, Ethiopia,

Email kirosseyoum@yahoo.com

Received: July 3I, 2018 | Published: September 06, 2018

\section{Introduction}

Ethiopia possess 2970 described animals species, among them, 320 are mammals with 36 endemics, 926 birds with 24 endemics, 1,249 arthropods with 11 endemics, 200 fish with 40 endemics, 202 reptiles with 17 endemics and 73 amphibians with 30 endemics. In addition, Ethiopia is also known as the home of 7,000 of higher plant species with $840(12 \%)$ of them are endemics. ${ }^{1}$ This biological diversity coupled with high number of endemics is associated with unique geological history, diverse climatic and physical conditions and topographical variation of the country. ${ }^{2,3}$ The geographical range of Ethiopian has distinctive altitudinal variations i.e. with the highest peak at Ras Dashen (4620 m above sea level) and minimum altitude (126 m below sea level) in the Afar depression. This creates diverse ecosystems (eg. forests, grass lands, wetlands and semi-arid environments) which have their own distinctive climatic conditions, and supports different plant and animals species including various bird species depending up on their habitat requirements. ${ }^{4-6}$

Therefore, the temporal and spatial species composition and abundance of birds in Ethiopia are mainly determined by vegetation structures used as food source, breeding sites and protection (shelter) resulting from climatic variations such as rainfall and temperature related to the topographical nature of a particular area. ${ }^{7,8}$ Physical environments such elevation, slope and aspect determine the composition, structure and productivity of vegetation which influences the diversity, abundance and habitat use of many birds. ${ }^{4}$

Birds are well known bio-indicators and they have a significant role in ecosystem functioning and balancing. Thus, they are agents of nutrient cycles, plant gene flow through pollination, seed dispersal, controls population size of harmful insects, environmental sanitation through scavenging of carrion. ${ }^{5}$ They are also used as a food sources, artistic and spiritual inspiration for many people throughout the world. ${ }^{9}$ Birds are also important components of tourism industries in many countries and they support the economic growth of a particular a country. ${ }^{7}$

According to Sethy et al., ${ }^{10}$ assessment of bird community is important tool in biodiversity conservation and identifications of conservation actions. Having knowledge on diversity and composition of bird communities is also crucial to determine the health status the local ecosystem or regional landscapes. Moreover, identifying the existing threats in a particular area is also essential for developing effective conservation efforts and management actions. ${ }^{8,11}$

Although, birds are among the key components of the earth's biodiversity, information on birds check list is still far from complete for most species in many countries including Ethiopia, and this might be an obstacle in the development effective conservation planning at the local/regional, national and global scales. ${ }^{67,12}$ In Ethiopia, some studies are conducted on the diversity, distribution and abundance of birds predominantly in protected areas such as National parks. ${ }^{4}$ However bird species composition, distribution, abundances and the threats that affect them are poorly understood in many regions of the country including the present study area. ${ }^{5}$ Therefore, understanding the diversity and relative abundance of birds from Wabe fragmented forest is deserves paramount importance for conservation of those locally inhabitants birds. 


\section{Material and methods}

\section{Study area}

The study was carried out in Wabe fragmented forest which is found in Wabe River catchment area at about $6 \mathrm{Km}$ away from both Wolkite town and Gubre subcity in Guraghe zone, Southern Nations, Nationalities and Peoples Region of Ethiopia. Wabe River catchment is a major sub basin of Omo-Gibe basin in the south western and central part of Ethiopia. It is located between 080 21'30" and 080
30 '00" $\mathrm{N}$ and 38005 '40" and 370 49'00"E (Figure 1). The area has an average temperature of $180 \mathrm{C}$ within a maximum temperature ranges from $200 \mathrm{C}$ (in the wet season) to $390 \mathrm{C}$ (in the dry season), while the minimum temperature ranges from $0-190 \mathrm{C}$. Its mean annual rainfall ranges from 1200 to $1320 \mathrm{~mm}$. The study area has a diversified woody plant species, with a major portion $(56 \%)$ is covered by shrubs and small trees. ${ }^{13}$ Wabe fragmented forest is surrounded by five kebeles of the Guraghe zone, namely Ewan, Gasore, Chancho, Qualakabod and Gereba (Figure 1).

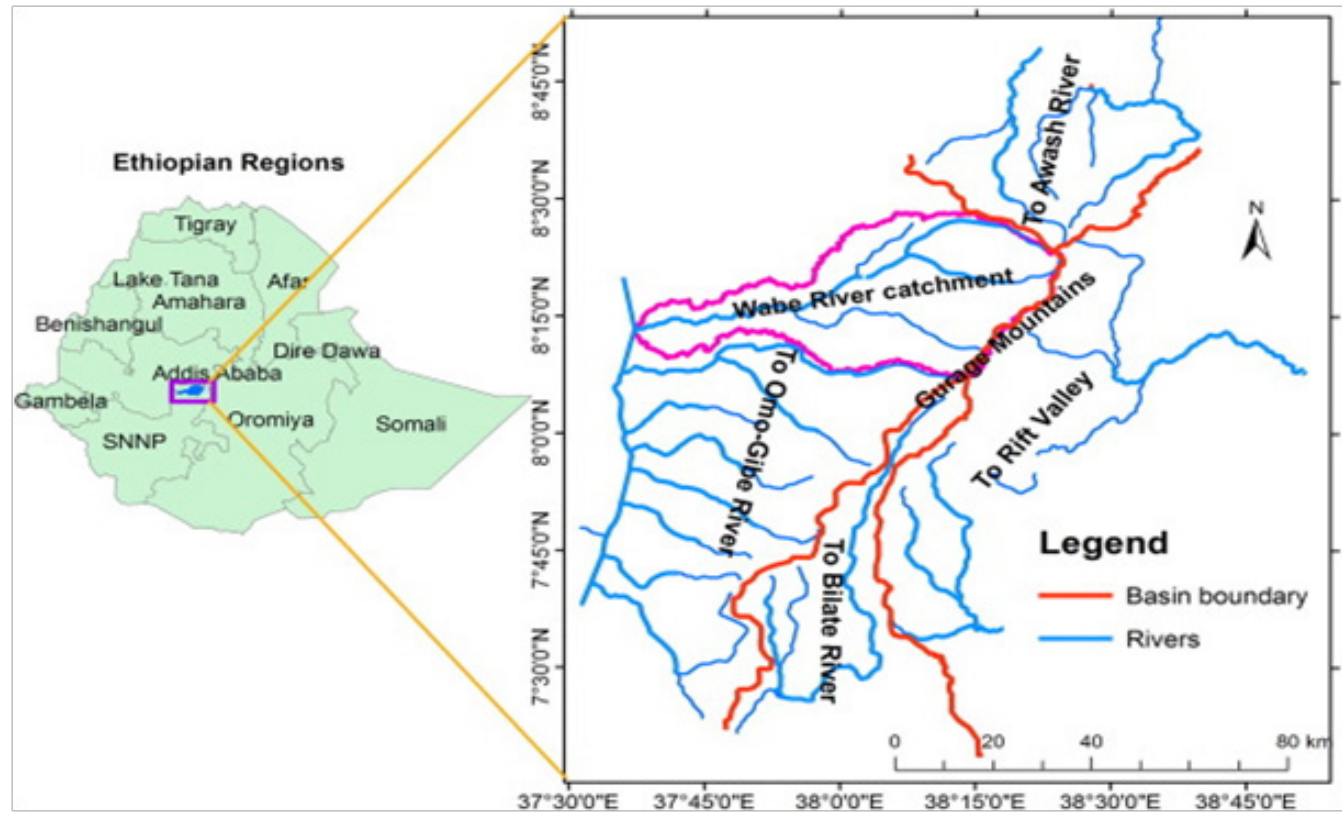

Figure I Map of Wabe River catchment Source: Sahle et al. ${ }^{14}$

The study area was stratified into three main habitats/sampling units named as bushland, plantation area and riverine forests as follows based on vegetation type, proximate to human settlements and presence of water.

Bushland: It covers the major portion of the study area. This site is dominated by shrubs and rarely large plants species are found predominantly the Cordia africana. This area is separated from nearest human settlements by Eucalyptus plants.

Plantation area: In this study the plantation area includes the area where human planted tree are found i.e. Eucalyptus plant species in the Wabe river catchment area.

Riverine forest: This site covers the open river environments, areas of left and right side of the river which has dense, large and woody forests. In this site primates such as Gureza and Vervet monkeys were frequently observed. In this site Wabe river is found in which the surrounded local residents utilizes for washing clothes and cars, drinking for livestock and bathing for themselves.

\section{Data collection}

Field data were conducted from three sampling sites in Wabe fragmented forests in April, 2018 for three consecutive days for each sampling site. Before data collection a preliminary survey was conducted to characterize the location of the study sites. Then data were collected using point and lines transect techniques to estimate the diversity and abundance of birds of Wabe fragmented forests. Line transect was used in bushland habitats, while point count was used in both plantation and riverine forests. In bushland habitat a total of four parallel line transects approximately $1.5 \mathrm{~km}$ length which had ten point transects were established. Moreover, during this stud a total of ten point count stations (five point stations each) were also systematically selected to enumerate birds of riverine forest and plantation habitats. Each point transect was at least $300 \mathrm{~m}$ far away from each other to avoid double counting of the same individual of a species following the methods of Girma et al., ${ }^{6}$ and Asefa et al. ${ }^{12}$ To minimize disturbance during enumeration, a waiting period of 3 to 5 minutes prior to counting was applied. ${ }^{5,7}$ Identification and enumeration of visible or heard birds was lasted for approximately 5 to 10 minutes at the radius of $30 \mathrm{~m}-50 \mathrm{~m}$ transect width depending based on the size and density of the forest. Each point transect was visited six times during the study period.

Field observations were started in the early morning (6:00-10:00 a.m.) and in the late afternoon (4:00-6:00 p.m.) when birds are active. During an observation: the list of species with their approximate population sizes, and threats were recorded. The available birds were observed by naked eye and using binoculars and then bird species were identified and taxonomically classified using bird guide book of Redman et al., ${ }^{15}$ and other standardized references. 


\section{Data analysis}

Data were arranged, organized and entered into Microsoft excel for analysis. Shannon-Weiner diversity index $\left(\mathrm{H}^{\prime}\right)$ was used to analyze bird diversity of the study area. It was calculated as:

$$
\mathrm{H}^{\prime}=-\sum_{\mathrm{i}=1}^{\mathrm{s}}\left(\frac{\mathrm{ni}}{\mathrm{N}}\right) \times \ln \left(\frac{\mathrm{ni}}{\mathrm{N}}\right)
$$

Where $\mathrm{H}^{\prime}=$ index of species diversity, ni is the number of individuals in a species, $\mathrm{S}$ is the total number of species, also called species richness, $\mathrm{N}$ is the total number of individuals.

Evenness index (J') was calculated by following the equation.

$$
\mathrm{J}^{\prime}=\frac{\mathrm{H}^{\prime}}{\ln \mathrm{S}}
$$

where: $\mathrm{H}=$ Shannon Weiner diversity index and $\mathrm{S}=$ Number of species

Richness index (D) was calculated by the following equation

$$
\mathrm{D}=\frac{\mathrm{S}-1}{\ln \mathrm{N}}
$$

Where: $\mathrm{D}=$ Richness index, $\mathrm{S}=$ Total number of species and $\mathrm{N}=$ Total number of individuals

Relative abundance of bird species was determined using encounter rates that give basic ordinal scales of abundance (abundant, common, frequent, uncommon and rare). ${ }^{16}$ Encounter rate for each species was calculated by dividing the number of birds recorded by the number of hours spent searching, giving a figure of birds per hour for each species. The abundance categories (the number of individuals per 100 field hours) were: $<0.1,0.1-2.0,2.1-10.0,10.1-40.0$ and $>40$. For each category, the following abundance score is given: 1 (rare), 2 (uncommon), 3 (frequent), 4 (common) and 5 (abundant) respectively. Moreover to understand bird community similarity among sites, Sorensen's coefficient was applied. ${ }^{7}$ It was calculated as:

$$
\mathrm{S}=\frac{3 \mathrm{c}}{\mathrm{A}+\mathrm{B}+\mathrm{C}}
$$

Where $\mathrm{S}=$ Sorenson's Coefficient, $\mathrm{c}$ is the number of species the three communities have in common, $\mathrm{A}$ is the total number of species found in community A, B is the total number of species found in community $\mathrm{B}$ and $\mathrm{C}$ is the total number of species found in community C. Sorenson's coefficient gives a value between 0 and 1 , the closer the value is to 1 , the more the communities have in common. To check the presence of variation in bird abundance among the three study sites, One Way ANOVA was used using SPSS version 16 computer software. Graphs were drawn by using Microsoft offices excel 2007 computer software.

\section{Result}

\section{Species composition of birds}

During the present study a total of 692 birds belonging to 50 species, 29 Families and 14 Orders were recorded from the study area. Order Passeriformes was numerically the dominant order represented with 22 species which accounts $44 \%$ of the identified species, while Bucerotiformes, Charadriiformes, Ciconiformes, Coliiformes and Piciformes were the least dominant orders represented with 1 species each (Figure 2). At the family level, family Accipitridae was numerically the dominant family represented with 7 species which accounts $14 \%$, of the identified species (Table 1). At species level, Common bulbul (Pycnonotus barbatus), White rumped babbler (Turdoides leucopygia) and Helmeted guineafowl (Numida meleagris) were numerically the dominant species with 37,87 and 171 number of individuals respectively, contributing $42.63 \%$ of the total bird abundance of the study area. Helmeted guineafowl (Numida meleagris) was the only bird species found in all study sites. From the 50 species identified in the study area, one species; Harwood's francolin (Pternistis harwoodi) is endemic to Ethiopia and four species are shared with Eretria; Black headed siskin (Serinus nigriceps), Abyssinian oriole (Oriolus monacha), Prince ruspoli's turaco (Tauraco ruspolii) and Wattled ibis (Bostrychia carunculata) which contributing $10 \%$ of the identified species (Table1), (Figure 2).

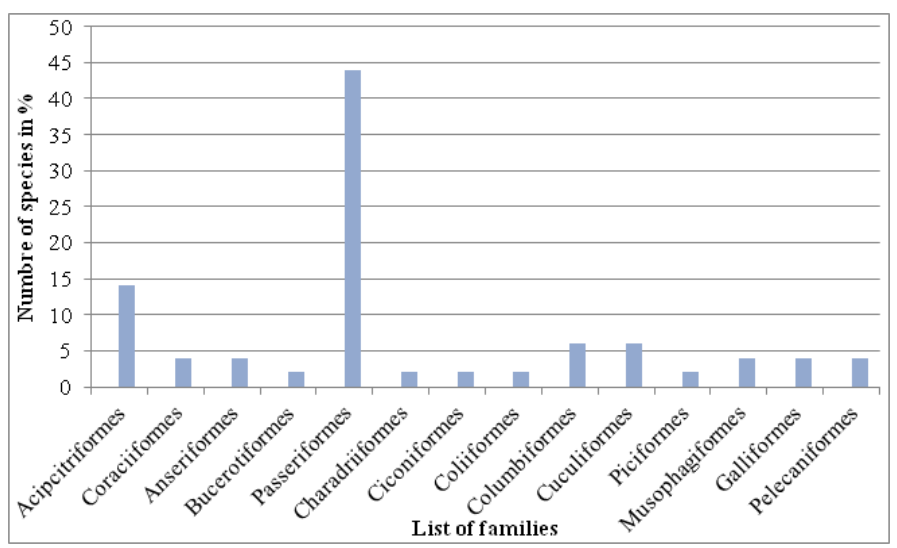

Figure 2 Percentage composition of different Orders of birds of the study area.

\section{Distribution and abundance of birds}

From the 50 species of birds identified during the study period, highest number; 36 species were recorded from bushland, and nearly similar number of species; 14 and 15 species were recorded from riverine forest and plantation area respectively. Twelve (24\%) common species were recorded in bushland and plantation habitats, and $3(6 \%)$ common species in bushland and riverine habitats (Table 3). Moreover, from the total 692 birds counted during the study period, 410 of them were recorded from bushland habitats, 122 and 160 birds from plantation and riverine forest habitats respectively. The total abundance of birds showed significant (ANOVA result, $p=0.00$ ) variation among the three study sites. The highest bird abundance was recorded in bushland, while the lowest was in plantation area (Figure $3)$.

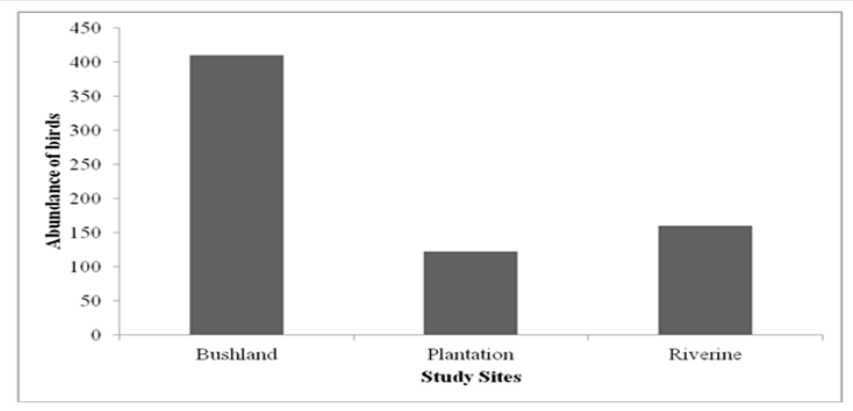

Figure 3 Spatial variations in the abundance of birds of the study sites. 
Table I List of bird species identified from the study area

\begin{tabular}{|c|c|c|c|}
\hline Order & Family & Scientific name & Common name \\
\hline \multirow[t]{7}{*}{ Acipcitriformes } & Accipitridae & Aquila spilogaster & African hawk Eagle \\
\hline & & Terathopius ecaudatus & Bateleur \\
\hline & & Necrosyrtes monachus & Hooded Vulture \\
\hline & & Accipiter minullus & Little-sparrow Hawk \\
\hline & & Lophaetus occipitalis & Long-crested Eagle \\
\hline & & Gyps rueppellii & Rueppell's Griffon \\
\hline & & Gyps africanus & White Backed Vulture \\
\hline \multirow[t]{2}{*}{ Coraciiformes } & Alcedinidae & Corythornis cristatus & Malachite Kingfisher \\
\hline & & Halcyon senegalensis & Woodland Kingfisher \\
\hline \multirow[t]{2}{*}{ Anseriformes } & Anatidae & Alopochen aegyptica & Egyptian Goose \\
\hline & & Anas undulata & Yellow-billed Duck \\
\hline Bucerotiformes & Bucerotidae & Tockus erythrorhynchus & Northern red-billed Hornbill \\
\hline Passeriformes & Campephagidae & Campephaga phoenicea & Red-shouldered Cuckooshrike \\
\hline Charadriiformes & Charadriidae & Vanellus senegallus & African Wattled Lapwing \\
\hline Ciconiformes & Coconiidae & Leptoptilos crumenifer & Marabuo Stork \\
\hline Coliiformes & Coliidae & Colius striatus & Speckled Mousebird \\
\hline \multirow[t]{3}{*}{ Columbiformes } & Columbidae & Streptopelia roseogrisea & African Collared Dove \\
\hline & & Streptopelia lugens & Dusky Turtle Dove \\
\hline & & Streptopelia capicola & Ring-necked Dove \\
\hline \multirow[t]{3}{*}{ Cuculiformes } & Cuculidae & Cuculus clamosus & Black Cuckoo \\
\hline & & Centropus monachus & Blue-headed Coucal \\
\hline & & Clamator levaillantii & Levaillant's Cuckoo \\
\hline \multirow[t]{4}{*}{ Passeriformes } & Estrildidae & Uraeginthus cyanocephalus & Blue-capped Cordon Bleu \\
\hline & & Lagonosticta senegala & Red-billed Firefinche \\
\hline & Fringillidae & Serinus nigriceps & Black-headed Siskin \\
\hline & Leiotrichidae & Turdoides leucopygia & White-rumped Babbler \\
\hline Piciformes & Lybiidae & Lybius bidentatus & Double-toothed Barbet \\
\hline \multirow[t]{4}{*}{ Passeriformes } & Malaconotidae & Laniarius aethiopicus & Ethiopian Boubou \\
\hline & & Terpsiphone viridis & African Paradise Flycatcher \\
\hline & Monarchidae & & \\
\hline & Motacillidae & Motacilla alba & White Wagtail \\
\hline \multirow[t]{2}{*}{ Passeriformes } & Muscicapidae & Saxicola torquatus & African Stonechat \\
\hline & & Cossypha semirufa & Rüppell's Robin Chat \\
\hline \multirow[t]{2}{*}{ Musophagiformes } & Musophagidae & Crinifer zonurus & Eastern Plantain Eater \\
\hline & & Tauraco ruspolii & Prince Ruspoli's Turaco \\
\hline \multirow[t]{2}{*}{ Passeriformes } & Nectariniidae & Chalcomitra senegalensis & Scarlet chested Sunbird \\
\hline & & Nectarinia tacazze & Tacazze Sunbird \\
\hline Galliformes & Numididae & Numida meleagris & Helmeted Guineafowl \\
\hline
\end{tabular}




\begin{tabular}{|c|c|c|c|}
\hline Order & Family & Scientific name & Common name \\
\hline \multirow[t]{2}{*}{ Passeriformes } & Oriolidae & Oriolus monacha & Abyssinian Oriole \\
\hline & & Oriolus larvatus & Black-headed Oriole \\
\hline Galliformes & Phasianidae & Pternistis harwoodi & Harwood's Francolin \\
\hline \multirow[t]{7}{*}{ Passeriformes } & Platysteiridae & Batis minor & Black-headed Batis \\
\hline & & Platysteira cyanea & Brown-throated Wattle Eye \\
\hline & Ploceidae & Bubalorins niger & Red-billed Buffallo Weaver \\
\hline & Pycnonotidae & Pycnonotus barbatus & Common Bulbul \\
\hline & Sturnidae & Lamprotornis pulcher & Chestnut-bellied Starling \\
\hline & & Lamprotornis chalybaeus & Greater Blue-eared Starling \\
\hline & & Poeoptera stuhlmanni & Stuhlmann's Starling \\
\hline \multirow[t]{2}{*}{ Pelecaniformes } & Threskiornithidae & Bostrychia hagedash & Hadada lbis \\
\hline & & Bostrychia carunculata & Wattled Ibis \\
\hline Passeriformes & Turdidae & Turdus abyssinicus & Mountain Thrush \\
\hline
\end{tabular}

\section{Species diversity and community similarity}

Bushland habitats had highest values of species diversity $\left(\mathrm{H}^{\prime}=\right.$ $2.89)$ and species richness ( $\left.{ }^{\prime}=5.82\right)$ than plantation and riverine forest habitats. Evenness index show slightly variation was found between plantation and riverine forest habitats, indicating that these two sites have less even distribution as compared with bushland with plantation, and bushland with riverine forest habitats (Table 2). The overall community similarity of the three study sites was low ( $\mathrm{S}=$ $0.06)$.

Table 2 Over all diversity, evenness and species richness indexes birds of the study sites

\begin{tabular}{lccccc}
\hline Study sites & S & N & D' $^{\prime}$ & $J^{\prime}$ & H' $^{\prime}$ \\
\hline Bushland & 36 & 410 & 5.82 & 0.81 & 2.89 \\
Plantation & 15 & 122 & 2.91 & 0.8 & 2.17 \\
Riverine forest & 14 & 160 & 2.56 & 0.82 & 2.16
\end{tabular}

\section{Relative abundance of birds}

In this study, based on relative abundance scores, among the 50 identified bird species, 37 (74\%) of them were uncommon species followed by $11(22 \%)$ rare species and $2(4 \%)$ as frequent species (Table 3). Majority of the species had low population sizes as a result they were grouped under rare and uncommon species. Only two species; Helmeted guineafowl and White rumped babbler are grouped under frequent species because they had relatively a greater number of individuals, i.e. with a population size of 171 and 87 individual birds respectively (Table 3 ).

+ denote the species present, - denote the species absent, ++ denote the species common to two habitats and +++ denote the species common to all study sites.
Table 3 Distribution and relative abundance of bird species

\begin{tabular}{|c|c|c|c|c|}
\hline $\begin{array}{l}\text { Common } \\
\text { name }\end{array}$ & Bushland & Plantation & Riverine & $\begin{array}{l}\text { Ordinal } \\
\text { scale }\end{array}$ \\
\hline $\begin{array}{l}\text { African hawk } \\
\text { eagle }\end{array}$ & - & + & - & Rare \\
\hline Bateleur & + & - & - & Rare \\
\hline Hooded vulture & ++ & - & ++ & Uncommon \\
\hline $\begin{array}{l}\text { Little } \\
\text { sparrowhawk }\end{array}$ & + & - & - & Rare \\
\hline $\begin{array}{l}\text { Long crested } \\
\text { eagle }\end{array}$ & - & - & + & Rare \\
\hline $\begin{array}{l}\text { Rueppell's } \\
\text { Griffon }\end{array}$ & - & - & + & Uncommon \\
\hline $\begin{array}{l}\text { White backed } \\
\text { vulture }\end{array}$ & ++ & - & ++ & Uncommon \\
\hline $\begin{array}{l}\text { Malachite } \\
\text { kingfisher }\end{array}$ & - & - & + & Rare \\
\hline $\begin{array}{l}\text { Woodland } \\
\text { Kingfisher }\end{array}$ & - & - & + & Rare \\
\hline Egyptian goose & - & - & + & Uncommon \\
\hline $\begin{array}{l}\text { Yellow billed } \\
\text { duck }\end{array}$ & - & - & + & Rare \\
\hline $\begin{array}{l}\text { Northern red } \\
\text { billed hornbill }\end{array}$ & + & - & - & Rare \\
\hline $\begin{array}{l}\text { Red shouldered } \\
\text { Cuckooshrike }\end{array}$ & + & - & - & Uncommon \\
\hline $\begin{array}{l}\text { African wattled } \\
\text { lapwing }\end{array}$ & - & - & + & Uncommon \\
\hline Marabuo stork & - & - & + & Uncommon \\
\hline $\begin{array}{l}\text { Speckled } \\
\text { mousebird }\end{array}$ & + & - & - & Uncommon \\
\hline $\begin{array}{l}\text { African collared } \\
\text { dove }\end{array}$ & ++ & ++ & - & Uncommon \\
\hline
\end{tabular}




\begin{tabular}{|c|c|c|c|c|}
\hline $\begin{array}{l}\text { Common } \\
\text { name }\end{array}$ & Bushland & Plantation & Riverine & $\begin{array}{l}\text { Ordinal } \\
\text { scale }\end{array}$ \\
\hline $\begin{array}{l}\text { Dusky turtle } \\
\text { dove }\end{array}$ & ++ & ++ & - & Uncommon \\
\hline $\begin{array}{l}\text { Ring necked } \\
\text { dove }\end{array}$ & ++ & ++ & - & Uncommon \\
\hline Black cuckoo & + & - & - & Rare \\
\hline $\begin{array}{l}\text { Blue headed } \\
\text { coucal }\end{array}$ & + & - & - & Uncommon \\
\hline $\begin{array}{l}\text { Levaillant's } \\
\text { cuckoo }\end{array}$ & + & - & - & Uncommon \\
\hline $\begin{array}{l}\text { Blue-capped } \\
\text { cordon-bleu }\end{array}$ & ++ & ++ & - & Uncommon \\
\hline $\begin{array}{l}\text { Red billed } \\
\text { firefinche }\end{array}$ & ++ & & - & Uncommon \\
\hline Abyssinian Siskin & - & + & - & Uncommon \\
\hline $\begin{array}{l}\text { White rumped } \\
\text { babbler }\end{array}$ & ++ & ++ & - & Frequent \\
\hline $\begin{array}{l}\text { Double toothed } \\
\text { barbet }\end{array}$ & + & - & - & Uncommon \\
\hline $\begin{array}{l}\text { Ethiopian } \\
\text { boubou }\end{array}$ & ++ & ++ & - & Uncommon \\
\hline $\begin{array}{l}\text { African paradise } \\
\text { flycatcher }\end{array}$ & + & & - & Uncommon \\
\hline White wagtail & - & - & + & Rare \\
\hline $\begin{array}{l}\text { African } \\
\text { stonechat }\end{array}$ & + & - & - & Uncommon \\
\hline $\begin{array}{l}\text { Rüppell's robin- } \\
\text { chat }\end{array}$ & + & - & - & Uncommon \\
\hline $\begin{array}{l}\text { Eastern plantain } \\
\text { eater }\end{array}$ & + & - & - & Uncommon \\
\hline $\begin{array}{l}\text { Prince ruspoli's } \\
\text { turaco }\end{array}$ & + & - & - & Uncommon \\
\hline $\begin{array}{l}\text { Scarlet chested } \\
\text { sunbird }\end{array}$ & + & - & - & Uncommon \\
\hline Tacazze sunbird & + & - & - & Uncommon \\
\hline $\begin{array}{l}\text { Helmeted } \\
\text { guineafowl }\end{array}$ & +++ & +++ & +++ & Frequent \\
\hline Abyssinian oriole & ++ & ++ & - & Uncommon \\
\hline $\begin{array}{l}\text { Black headed } \\
\text { oriole }\end{array}$ & + & - & - & Uncommon \\
\hline $\begin{array}{l}\text { Harwood's } \\
\text { francolin }\end{array}$ & ++ & ++ & - & Uncommon \\
\hline $\begin{array}{l}\text { Black headed } \\
\text { batis }\end{array}$ & + & - & - & Uncommon \\
\hline $\begin{array}{l}\text { Brown throated } \\
\text { wattle eye }\end{array}$ & + & - & - & Uncommon \\
\hline $\begin{array}{l}\text { Red billed } \\
\text { buffallo weaver }\end{array}$ & + & - & - & Uncommon \\
\hline Common bulbul & ++ & ++ & - & Uncommon \\
\hline $\begin{array}{l}\text { Chestnut bellied } \\
\text { starling }\end{array}$ & + & - & - & Uncommon \\
\hline $\begin{array}{l}\text { Greater blue } \\
\text { eared starling }\end{array}$ & - & + & - & Rare \\
\hline $\begin{array}{l}\text { Stuhlmann's } \\
\text { starling }\end{array}$ & + & - & - & Uncommon \\
\hline Hadada ibis & - & - & + & Uncommon \\
\hline Wattled ibis & - & - & + & Uncommon \\
\hline Mountain thrush & ++ & ++ & - & Uncommon \\
\hline Total & 36 & 15 & 14 & \\
\hline
\end{tabular}

\section{Discussion}

Exploration of species composition and abundance of birds from unprotected habitats is very essential to understand the health of the environments and to develop effective and sustainable bird conservation strategies and managements measures. ${ }^{17}$

In this study, order Passeriformes was numerically the dominant order represented with 22 species from the 50 identified species which accounts $44 \%$ of the identified species. This result is in agreement with Desalgn \& Subramanian ${ }^{4}$ in Angereb forest and adjacent farm land in Northwestern Ethiopia and Tesfahunegny et al. ${ }^{5}$ in Kafa biosphere reserve, Southwest Ethiopia. They reported among the 89 and 42 species identified respectively, $66.3 \%$ and $47.6 \%$ of the species are belonged to the order Passeriformes.

The present study in Wabe fragmented forest, showed that bushland/shrub land support a considerable number of bird species (72\%) and bird abundance $(59.25 \%)$ as compared to riverine forest and human plantation habitats. This is in line with result of Desalgn \& Subramanian, ${ }^{4}$ Girma et al. ${ }^{8}$ Aynalem \& Bekele. ${ }^{16}$ Bergner et al. ${ }^{17}$ and Mengesha et al., ${ }^{18}$ where high species diversity, richness and abundance of birds was observed in bushland habitat that might be associated with the vegetation composition that could create variations in food sources, nesting and protection opportunities based up on the bird's habitat preference and feeding habits.

Moreover, the presence of low species richness and abundance in the riverine forest might be associated with presence of homogeneous plant species which are selected only by few bird species. According to Girma et al., ${ }^{8}$ a natural forest which is dominated by few tree species is not suitable to different bird species, because it does not fulfilled the feeding or nest building preferences of most species coupled with risk of predation and thus, it is preferred by few forest specialist bird species alone as they obtained sufficient cover and food requirements. In contrast, Mengesha \& Bekele., ${ }^{2}$ has reported highest avian species diversity was found in riverine woodland habitat in Alatish National Park, this variation might be associated with type of plant species found and feeding habit of the presented bird species. In addition to this, in this site different bird species were recorded including aquatic and scavenger birds. This in line with Girma et al., ${ }^{8}$ report, although some natural forest are less preferred by most bird species, but they provided bird refugee for the surrounding locality avian fauna where they get better protection, foraging, nesting building and roosting opportunities.

The low species richness and abundance of birds in the human planted eucalyptus and other exotic plant species is also reported in other studies; conifer plantations in southwestern Turkey ${ }^{17}$ and eucalyptus plantation in Brazi $1{ }^{19}$ and Northwest Portugal. ${ }^{20}$ This might be due to exotic plants leads to loss of structural components for birds, such as appropriate substrates for foraging and nesting requirements associated with the plant properties and homogeneity habitat creation nature of these plants. ${ }^{17,19}$ Among the 15 species identified from the plantation habitat, $12(24 \%)$ of them were also occurred in bushland habitats. Similar result is also reported by Jacoboski et al., ${ }^{19}$ plantations are functional habitats for a subset of local native forest species which serve as an occasional habitat predominantly for generalist species. This is determined by the tolerance or adaptation of the particular species in those changed or modified habitats as some species are build their nests, while other species are used as a migratory corridors/ route to other habitats. ${ }^{19}$ According to Sreekar et al., ${ }^{21}$ natural forests are irreplaceable for biodiversity conservation as more than half of the local bird species do not occupy monoculture rubber plant species 
even when in close proximity to natural forests with in less than 100 meter distance.

In this study the helmeted guinea fowl was numerically the most dominant bird species in all study sites contributing $24.71 \%$ of the identified bird species. According to Girma et al., ${ }^{8}$ the helmeted guinea fowl display relatively social, gregarious behavior occurring in flocks during foraging, this might helped as a defensive strategy of this bird even in distributed habitats or in the presence of natural predators. Moreover, the variation in species dominance among different habitats could also be attributed to the presence food availability, suitable cover and nesting sites, adaptation or tolerance level of the species and the degree of the threats presented in the habitats. ${ }^{8}$ But based on the relative abundance score, most of the occurred bird species were grouped under locally rare and uncommon species. Similar result is reported by Mengesha \& Bekele ${ }^{2}$ from Alatish National Park, North Gondar, Ethiopia, thus the occurrence of such species indicates there is a need of wildlife conservation prioritization in those habitats.

Although the study area harbors a considerable number of species including endemic birds, the study area is highly fragmented and exposed to different threats caused by anthropogenic activities. The main threatened factor for birds and biodiversity in general observed in the study area includes overgrazing and deforestation due to agricultural explanation, road constructions, human settlements, fire wood and charcoal productions and eucalyptus plantation expansions. As a result the native forest habitats are degraded and become fragmented and consequently these might be affected the survival of those locally inhabitant bird species. According to Sreekar et al., ${ }^{21}$ anthropogenic driven habitat loss due to agricultural expansions is currently at faster rate than any time within the past 50 years, predominantly in developing nations including our country. Change in vegetation community structure due to human activities could be altering the availability and quality of food, shelter and nesting sites and water. This might be lead to alter the diversity, abundance and distribution of birds of a particular habitats or it may lead to additional problems such as risk of predation or cost of migration for searching food or nest sites. ${ }^{18}$ In some case habitat disturbance has led to an overall increase in avian diversity, and in the abundance of most avian species in some areas, but it has a negative impact for forest specialist species as they do not have any alternative foraging or breeding sites. ${ }^{12}$ According to Asefa et al., ${ }^{11}$ allowing large and repetitive livestock population in to unprotected area will also lead to los of grassland specialist bird species.

\section{Conclusion}

During the present study various bird species were recorded from the study sites. From the present study it is clear that, the bird species composition and abundance varied among the three study sites. Bird species composition and abundance was highest in bushland habitats related to the presence different of plant species which supported different birds as food source and nesting sites. Among the fourteen order identified, order Passeriformes was numerically the dominant order encompassed 22 different bird species. In addition, from the 50 identified bird species, helmeted guinea fowl was numerically the most dominant bird species indicating an adaption of the species to different habitat types. Overgrazing and deforestation through agricultural explanation, road constructions, human settlements, fire wood and charcoal productions and eucalyptus plantation expansions were observed in the study area which affects the survival of theses bird through foraging and breeding site loss. Therefore, urgent conservation and management efforts are needed to reduce theses multiple threats and to enhance survival rate of the birds and other co-occurring wildlife species.

\section{Recommendation}

i. With respect to conservation measures, these findings stress the importance of Wabe fragmented forests supporting different species of birds. Based on the results which are obtained during the study period, the following recommendations are made.

ii. Wabe forests harbors different birds including endemic birds, but they are unprotected and threatened by anthropogenic factors, so, wildlife conservation and management's efforts are mandatory.

iii. The state or federal government should be given an attention to protect this area, as the area is naturally gifted by having different plant species, birds, antelopes, primates and water body i.e. Wabe river, if this area is protected, hopefully it might support Gurage zone, in particular to the local communities as a source of economic growth through truism industry by watching or trophy hunting of wildlife.

iv. Eucalyptus plantation expansions is observed in the study area and hence, wilderness of the native forest is reduced and fragmented, and thus, local community awareness is essential to develop native plant species planting adaptation to reduce the impact of eucalyptus plant on the native ecosystem or biodiversity in general.

\section{Acknowledgements}

None.

\section{Conflict of interest}

Author declares that there is no conflict of interest.

\section{References}

1. Tesfahunegny W. A catalogue for endemic birds of Ethiopia. Journal of zoology. 2016;3(4):109-133.

2. Mengesha G, Bekele A. Diversity and relative abundance of birds of Alatish National Park, North Gondar, Ethiopia. International Journal of Ecology and Environmental Sciences. 2008;34:215-222.

3. Getahun AA. The status of ecosystem resources in Ethiopia: Potentials, Challenges and Threats: Review Paper. Journal of Biodiversity and Endangered Species. 2018;6:2332-2543.

4. Desalgn A, Subramanian C. Studies on avian diversity in Angereb forest and adjacent farm land with reference to rainy and post rainy seasons, Northwestern Ethiopia. International journal of pure and applied zoology. 2015;3:219-225.

5. Tesfahunegny W, Fekensa T, Mulualem G. Avifauna Diversity in Kafa Biosphere Reserve: Knowledge and Perception of Villagers in Southwest Ethiopia. Ecology and Evolutionary Biology. 2016;1(2):7-13.

6. Girma Z, Mengesha G, Asfaw T. Diversity, relative abundance and distribution of avian fauna in and around Wondo Genet forest, Southentral Ethiopia. Research Journal of Forestry . 2017;11(1):1-12.

7. Areaya H, Yonas M, Haileselasie TH. Community composition and abundance of residential birds in selected church forests, Tigray Region,Northern Ethiopia. Scientific Research and Essays. 2013;8(22):1038-1047.

8. Girma Z, Mamo Y, Mengesha G, et al. Seasonal abundance and habitat use of bird species in and around Wondo Genet Forest, south-central Ethiopia. Ecol Evol. 2017;7(10):3397-3405 
9. Whelan CJ, Sekercioglu CH, Wenny DG. Why birds matter: from economic ornithology to ecosystem services. Journal of Ornithology. 2015;156(supply 1);1-13.

10. Sethy J, Sama D, Sethi S, et al. Species diversity and abundance of birds in and around North Orissa University, Takatpur, Baripada, Mayurbhanj, Odisha. International Journal of Innovative Research in Science, Engineering and Technology. 2015;4(2):1-12

11. Asefa A, Mengesha G, Shimelis A, et al. Livestock Grazing Afromontane Grasslands in the Northern Bale Mountains, Ethiopia: Implications for Bird Conservation. Science, Technology and Arts Research Journal. 2015;4(2):112-121.

12. Asefa A, Davies AB, McKechnie AE, Kinahan AA, et al. Effects of anthropogenic disturbance on bird diversity in Ethiopian montane forests. Ornithological Applications. 2017;119(3):416-430.

13. Sahle M, Fürst C, Yeshitela K. Plant diversity analysis for conservation of Afromontane vegetation in socio-ecological mountain landscape of Gurage,South Central Ethiopia. International Journal of Biodiversity and Conservation. 2018;10(4):161-171.

14. Sahle M, Fürst C, Saito O, et al. Quantification and mapping of the supply of and demand for carbon storage and sequestration service in woody biomass and soil to mitigate climate change in the socio-ecological environment. Sci Total Environ. 2018;624:342-354.

15. Redman N, Stevenson T, Fanshawe J. Birds of the Horn of Africa: Ethiopia, Eritrea, Djibouti, Somalia, and Socotra. 2nd ed. Christopher Helm, London, UK. 2011;460
16. Aynalem S, Bekele A. Species composition, relative abundance and distribution of bird fauna of riverine and wetland habitats of Infranz and Yiganda at southern tip of Lake Tana, Ethiopia. Tropical Ecology. 2008;49(2):199-209.

17. Bergner A, Avci M, Eryigit H, et al. Influences of forest type and habitat structure on bird assemblages of oak (Quercus spp.) and pine (Pinus spp.) stands in Southwestern Turkey. Forest Ecology and Management. 2015:336:137-147.

18. Mengesha G, Mamo Y, Bekele A. A comparison of terrestrial bird community structure in the undisturbed and disturbed areas of the Abijata Shalla lakes national park, Ethiopia. International Journal of Biodiversity and Conservation. 2011;3(9):389-404.

19. Jacoboski LI, de Mendonça-Lima A, Hartz SM. Structure of bird communities in eucalyptus plantations: nestedness as a pattern of species distribution. Braz J Biol. 2016;76(3):583-591.

20. Proença VM, Pereira HM, Guilherme J, et al. Plant and bird diversity in natural forests and in native and exotic plantations in NW Portugal. Acto Oecologica. 2010;36(2):219-226.

21. Sreekar R, Huang G, Yasuda M, et al. Effects of forests, roads and mistletoe on bird diversity in monoculture rubber plantations. Scientific Reports. 2016;6:218-22. 